Kultur \& Klasse 30

\title{
Socialisation
}

Bent Fausing behandler forholdet mellem æstetik og socialisation i massekulturindustrien og facismens inddragelse af kunsten i den autoritære opdragelsesproces. Elo Nielsen analyserer beatmusikken ud fra en socialisationsteoretisk synsvinkel.

Peter Brückner interviewes om æstetisk-politisk opdragelse i DDR og Michel Foucault om straf- og disciplineringsformer $i$ »socialistiske« samfund.

Kr. 35,65, 125 sider, ill.

Kultur \& Klasse 32

\section{Historie -}

bevidsthedshistorie

Jens Hougaard analyserer problemer i borgerlig historieforskning, Søren Baggesen kritiserer den objektivistiske historieforståelse, Martin Zerlang diskuterer problemer ved analyse af førkapitalistiske bevidsthedsformer, Jørgen Holmgaard og Torben Kragh Grodal behandler træk af 1848-1901 som litteraturhistorisk periode.

Kr. 35, 65, 128 sider. 